\title{
Historical and current status of vultures in Myanmar
}

\author{
HTIN HLA, NAY MYO SHWE, THURA WIN HTUN, SAO MYO ZAW, \\ SIMON MAHOOD, JONATHAN C. EAMES and JOHN D. PILGRIM
}

\begin{abstract}
Summary
Concerns for the long-term survival of vulture populations on the Indian Subcontinent, owing to widespread poisoning by the veterinary drug diclofenac, have led to increased conservation focus on South-East Asian countries where diclofenac is not used and relict populations of vultures occur. We document here how White-rumped, Slender-billed and Red-headed Vultures have declined substantially in abundance and contracted in range in Myanmar over the last 50 years. Using a vulture restaurant method we determined that the population of vultures in Myanmar is at least 136 individuals, made up of at least: 62 White-rumped Vultures, 21 Slender-billed Vultures, 51 Himalayan Vultures and two Red-headed Vultures. The decline in the resident Gyps species is most likely due to declines in wild ungulate populations. Our population estimates are provisional and the survey covered only a proportion of the possible vulture range within Myanmar. Himalayan Vultures were not recorded in Myanmar in historical times, and possible reasons for the recent upsurge in records are discussed. Myanmar presents an opportunity of global significance for vulture conservation, due to the persistence of three Critically Endangered vulture species in a country where diclofenac is not used.
\end{abstract}

\section{Introduction}

Historically, vultures were widespread and common in Asia, but White-rumped Vulture Gyps bengalensis, Indian Vulture Gyps indicus, Slender-billed Vulture Gyps tenuirostris and Redheaded Vulture Sarcogyps calvus have undergone rapid, extensive, and catastrophic population declines in India, Nepal and Pakistan within the last 20 years owing to accidental poisoning by diclofenac (an anti-inflammatory drug) in domestic cattle carcasses (Prakash 1999, Thiollay 2000, Virani et al. 2001, Gilbert et al. 2002, Prakash et al. 2003, Green et al. 2004, Oaks et al. 2004, Cuthbert et al. 2006, Das et al., in press). These four species are now listed as globally "Critically Endangered", reflecting their extremely high risk of extinction in the immediate future (BirdLife International 2010a).

Dramatic declines in vulture populations across the Indian Subcontinent have increased conservation focus on relict populations in South-East Asia. During the first half of the twentieth century, White-rumped Vulture, Slender-billed Vulture and Red-headed Vulture were considered widespread and at least locally common or abundant across South-East Asia (Ferguson-Lees and Christie 2001, Pain et al. 2003). By the end of that century, these species had been extirpated from all but Myanmar and northern Cambodia, and parts of adjacent Laos (BirdLife International 2001, Pain et al. 2003), with low breeding success reported in remaining Gyps in Cambodia (Timmins and Ou Ratanak 2001).

The increased importance of these small, but diclofenac-free, populations stimulated systematic population surveys. In Cambodia, the population was surveyed in 2004 using a vulture restaurants method and, except for the following year, counts have continued annually since (Wildlife 
Conservation Society et al. 2005). Recent simultaneous counts at seven vulture restaurants in northern Cambodia provided minimum population totals of 182 White-rumped Vultures, 4I Slender-billed Vultures and 43 Red-headed Vultures, with the overall vulture population assessed as stable or slightly increasing (Pech Bunant and Rainey 2009). The recent status and trends of vulture populations in Myanmar are very unclear (BirdLife International 2001, Pain et al. 2003). Since these, together with the Cambodian populations, potentially constituted a significant - and importantly, probably diclofenac-free - proportion of the global population of White-rumped Vulture, Slender-billed Vulture and Red-headed Vulture, a project was initiated in Myanmar to: (i) assess the status, distribution, and trends of vulture populations; (ii) locate breeding colonies of vultures; (iii) identify threats to vulture populations; and (iv) formulate a conservation action plan for vultures in Myanmar.

\section{Methods}

To assess the historical and current status and distribution of Gyps and Sarcogyps species in Myanmar, published literature and unpublished reports were collated, and unpublished sightings were collected from observers known to have recently visited the country.

Areas for field survey were selected where there had been records from the last 12 years, regardless of historical records or recent survey effort. Kachin State, Sagaing Division, Shan State and Chin State were selected. Across these administrative divisions, surveys were conducted at sites approximating a transect across the northern part of the country. Sites were chosen for their contribution to overall geographic coverage, complementarity to recent surveys, relative accessibility and political stability. Southern and eastern areas of Shan State were, owing to civil conflict, avoided. Apart from the first site, which was used for standardisation of methodology, all sites were situated at least $50 \mathrm{~km}$ apart in an effort to reduce (albeit not necessarily eliminate) double-counting of birds among sites. From these surveys absolute minimum population estimates for each species were generated by summing the maximum number of adults and sub-adults at any one restaurant.

The surveys were a collaborative effort between the Biodiversity and Nature Conservation Association (BANCA), BirdLife International in Indochina and the Nature and Wildlife Conservation Division (NWCD), Forest Department, Ministry of Forestry of Myanmar. The survey team comprised NMS, TWH and SMZ. The first phase of surveys lasted from 5 December 2006 to 20 March 2007; starting in Kachin State, moving south into Shan State and to the Thai border, returning to central Kachin State, heading first north and then south-west along the Chindwin River into northern Sagaing Division. The second phase of surveys was conducted in Chin State, from 15 April to 3 May 2007. Surveys comprised interviews with local communities and conducting 'vulture restaurants', where dead cattle or buffalo were provided to attract vultures and counts then made of vulture numbers. Efforts were also made to collect information on threats to vultures.

At each site, a suitable location for a vulture restaurant was selected, usually a cleared area or sandbar of at least 0.4 ha in size with very little or no vegetation, in order that a carcass would be easily visible to soaring vultures. A small hide was then constructed at the edge of each clearing, about $30 \mathrm{~m}$ from each carcass in order that vultures would not be disturbed yet clear observations could be made. Hides were built facing north for best lighting to facilitate easy identification of vulture species, age and sex. After community interviews, a large domestic cow or buffalo was bought and slaughtered, with species choice based on availability and cost. The oldest or youngest animals were often bought, owing to their lower price, but sick animals were never purchased. Since carcasses were fresh, and vultures cannot open the skin of large ungulates, an incision was made on the skin of the belly of each carcass to facilitate access by vultures to the flesh and abdominal cavity. Surveyors entered the hide at first light and remained until dusk, for three consecutive days at each restaurant site. Number, species, age, and sex of vultures visiting the restaurant were recorded from inside the hide, taking care to avoid double-counting. Photographs 
were also taken, and other bird species attracted to the carcass noted. To prevent removal of meat from carcasses by feral dogs or people, carcasses were guarded overnight.

\section{Results}

Historical and recent records of vultures in Myanmar

\section{Egyptian Vulture Neophron percnopterus}

Listed as a vagrant to eastern Myanmar by Robson (2005) based on a sight record by Hopwood in 1941-42 mentioned in Smythies (1986). No recent records.

\section{White-rumped Vulture Gyps bengalensis}

Most historical reports suggest that this was a common and widespread breeding species in Myanmar during the first half of the last century, being abundant in the plains, particularly near Gurkha cattle-breeding villages (Macdonald 1906, Hopwood 1912, Stanford and Ticehurst 1935, 1938-1939). Only Christison et al. (1946) regarded it as scarce, believing it solely to be present between November and April in the coastal parts of Arakhan State and the foothills of the Yomas. Historical sources indicate that it breeds from November to February (Macdonald 1906, Stanford and Ticehurst 1935 and 1938-1939, Roseveare 1950).

The first recent record of the species was from the Chin Hills in 1995 (Robson et al. 1998) Subsequently, it has been regularly recorded with other Gyps species from 1997 to 2006 in Shan State, Chin State, Kachin State and upper Sagaing Division (HH unpublished data, Uthai in litt. 2002, Sein Myo Aung in litt.). In June 2003, 78 individuals were recorded in a single flock in southern Shan State (Htin Hla pers. obs.). From 13-24 January 2004, five groups of between 1-10 individuals were observed near Lotaw village in the central Chin Hills (JCE unpublished data). In all of five expeditions to northern Kachin state (i.e. Tanai, Kamaing and Bhamaw) from 2002 to 2006 by BANCA and BirdLife International, significant numbers of Gyps vultures were seen. For instance, 62 White-rumped Vultures were seen together on 18 October 2005 near the Nat Kaung River in the northern lowlands of Kachin State (Tordoff et al. 2007). At least 30 were recorded in the remote Hukaung Valley in northern Myanmar in December 2005-January 2006 (Robson 2006). Most recently, five were seen near Kalay Wa on 30 August 2006 (Sein Myo Aung in litt.).

\section{Slender-billed Vulture Gyps tenuirostris}

All historical reports describe Slender-billed Vulture as a common species in Myanmar (Hopwood 1912, Christison et al. 1946, Roseveare 1950), although less so than White-rumped Vulture (Stanford and Ticehurst 1938-1939). There are historical records from Arakhan State (Hopwood 1912, Stanford and Ticehurst 1938-1939, Christison et al. 1946), Minbu District (Roseveare 1950), and central Myanmar and southern Shan State (Stanford and Ticehurst 1938-1939).

Recent records of the species, from 1997 to 2006, indicate that Gyps vultures persist in small numbers in Shan State, Chin State, Kachin State and upper Sagaing Division (Htin Hla unpublished data from 1997, 1999 and 2002, Uthai in litt. 2002, Sein Myo Aung in litt.). Nine were recorded in a flock with 78 White-rumped Vultures in southern Shan State in 2003 (Htin Hla pers. obs. 2003). Significant numbers of Gyps vultures were recorded on all expeditions to northern Kachin state (i.e. Tanai, Kamaing and Bhamaw) between 2002 and 2006 by BANCA and BirdLife International; for example, in 2005, 12 Slender-billed Vultures were seen at a vulture restaurant near the Nat Kaung River (Tordoff et al. 2007). At least six were seen in the Hukaung Valley in northern Myanmar in December 2005-January 2006 (Robson 2006). 


\section{Himalayan Vulture Gyps himalayensis}

Not listed historically for Myanmar, although Stanford and Ticehurst (1938-1939) believed that the species would probably be found along the snow-covered mountains north of Fort Hertz (Putao) in extreme northern Kachin State, along with Lammergeier Gypaetus barbatus.

Unlike Lammergeier, there have been a number of records of this species in recent years. The first record for Myanmar was of an individual killed by a person from Rezwar town in the central Chin Hills in January 2004; a skin photographed by the survey team was identified as a juvenile Himalayan Vulture by JCE. The first live record was of four adults and seven sub-adults on a domestic buffalo carcass $8 \mathrm{~km}$ north-east of Indawgyi Lake on 30 November 2004, together with White-rumped and Slender-billed Vultures. On 6 December 2004, a single adult was recorded at Kamaing town and two adults and 21 sub-adults were seen about $5 \mathrm{~km}$ south of Kamaing town (Tordoff et al. 2007). On 29 November 2005, five Himalayan Vultures were recorded together on Phonganrazi mountain, Kachin State (Sein Myo Aung, Karin Eberhardt and SMZ unpublished data).

\section{Red-headed Vulture Sarcogyps calvus}

Most historical sources consider this species to have been less abundant than either of the known resident Gyps species. Macdonald (1906) stated that it was common nowhere, whilst Roseveare (1950) describes it as fairly common during the breeding months (January to March) and less so in other months, hinting at the possibility of seasonal movements or perhaps just a bias in detection rate. In Arakhan State, Hopwood (1912) describes it as rather rare, in contrast to Christison et al. (1946) who described it as common there. Stanford and Ticehurst (1935, 19381939) state that "Black Vulture Sarcogyps calvus", presumably Red-headed Vulture, was present in small numbers all over the Sittang Irrawaddy plain (including nests in Rangoon (=Yangon) and the old Pilakat Reserve), common in northern Myanmar (including evidence of breeding near Myitkyina, Kachin State), not uncommon (and probably breeding) in the Prome District of lower Burma (= Bago Division), and occurring in summer in Yunnan Province, China.

There are a small number of recent records. In mid-March 2003, one was seen near Haipak village, Nam Sam Township, Shan State, and on 16 March four were seen with 45 White-rumped Vultures near Cali village in the same township (Saw Moses pers. comm.) On 18 and 19 April, two were seen near Haipak village, Namsam Township, Shan State with nine White-rumped Vultures (Saw Moses and Kopan pers. comm.)

\section{Cinereous Vulture Aegypius monachus}

Listed as a rare winter visitor to Myanmar by Robson (2005). The only historical record is of a single bird on a sand bar 7 miles downstream of Myitkyina, Kachin State, on 23 November 1934, although there is also an undated report from Bhamo District (Stanford and Ticehurst 1938-1939). Four recent records exist, all of single birds: in Yangon on 24 December 2001 (Joost van der Ven in litt.); along the Myithar River south of Kalewa (Chin State) in 2004 (Joost van der Ven in litt.); with five Himalayan Vultures in Phonganrazi mountain region, Kachin State on 29 November 2006 (Sein Myo Aung, Karin Eberhardt and SMZ unpublished data); and a rehabilitated bird released just across the border in Thailand in May 2007. This latter individual was satellitetracked into south-eastern Shan State, where it was shot dead by a villager (Casey 2007).

\section{Vulture restaurant surveys}

Of twenty vulture restaurants conducted, vultures were recorded at nine (Table 1 ). Locations of vulture restaurant sites are shown in Figure 1 and detailed in Appendix 1. In Kachin State and upper Sagaing Division most sites were located in floodplains of rivers and lakes, usually on 


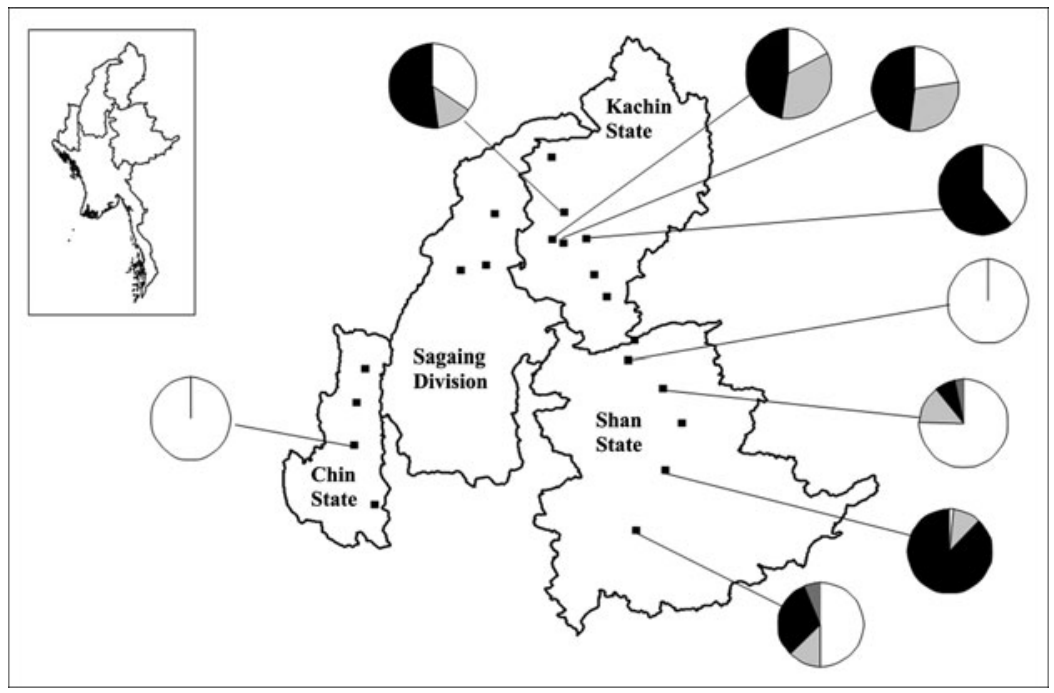

Figure 1. Locations of vulture restaurants (filled squares) and species composition (circles: white $=$ Himalayan Vulture; light grey $=$ Slender-billed Vulture; black $=$ White-rumped Vulture; dark grey $=$ Red-headed Vulture), with inset of Myanmar showing four survey regions.

sandbars. Tall grass or similar dense vegetation of $2-3 \mathrm{~m}$ in height surrounded most restaurant sites. Most sites were within sight of mountains exceeding 1,00o m altitude. In Shan State, sites were located on high elevation plateaux, usually in abandoned fields or areas of shifting cultivation close to human habitation and surrounded by degraded habitats. In Chin State, sites were situated at high elevations in clearings or areas of montane savannah surrounded by primary montane forest.

At most successful restaurants, the first vulture arrived after four to six hours, first circling above the carcass, before landing in trees near the restaurant. In a few cases, vultures arrived at restaurants as early as two hours after the carcass was deposited. There was always fierce

Table 1 . Maximum numbers of vultures at each successful vulture restaurant $(\mathrm{A}=$ Adult; $\mathrm{SA}=$ Subadult; $\mathrm{J}=$ Juvenile).

\begin{tabular}{|c|c|c|c|c|c|}
\hline \multirow[t]{2}{*}{ Site } & \multicolumn{4}{|l|}{ Species } & \multirow[t]{2}{*}{ Total } \\
\hline & $\begin{array}{l}\text { Red-headed } \\
\text { Vulture }\end{array}$ & $\begin{array}{l}\text { White-rumped } \\
\text { Vulture }\end{array}$ & $\begin{array}{l}\text { Slender-billed } \\
\text { Vulture }\end{array}$ & $\begin{array}{l}\text { Himalayan } \\
\text { Vulture }\end{array}$ & \\
\hline 1 & o & $27(17 \mathrm{~A}, 10 \mathrm{~J})$ & $20(12 \mathrm{~A}, 8 \mathrm{~J})$ & $10(\mathrm{IOJ})$ & 57 \\
\hline 2 & o & $13(8 \mathrm{~A}, 5 \mathrm{~J})$ & $8(6 \mathrm{~A}, 2 \mathrm{~J})$ & $6(6 \mathrm{~J})$ & 27 \\
\hline 6 & o & o & o & 19 (19J) & 19 \\
\hline 7 & 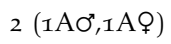 & $5(5 \mathrm{~J})$ & $9(5 \mathrm{~A}, 4 \mathrm{~J})$ & $49(49 \mathrm{~J})$ & 65 \\
\hline 9 & o & $60(52 \mathrm{~A}, 8 \mathrm{~J})$ & $7(5 \mathrm{~A}, 2 \mathrm{~J})$ & $I(\mathrm{IJ})$ & 68 \\
\hline 10 & $I\left(1 \mathrm{AO} \sigma^{\top}\right)$ & $5(4 \mathrm{~A}, \mathrm{IJ})$ & $2(1 \mathrm{~A}, \mathrm{IJ})$ & $8(8 \mathrm{~J})$ & 16 \\
\hline 11 & o & $19(12 \mathrm{~A}, 7 \mathrm{~J})$ & o & 12 (12J) & 31 \\
\hline 12 & o & $12(6 \mathrm{~A}, 6 \mathrm{~J})$ & $3(2 \mathrm{~A}, 1 \mathrm{~J})$ & $8(8 \mathrm{~J})$ & 23 \\
\hline 18 & o & o & o & $50(48 \mathrm{~J}, 2 \mathrm{SA})$ & 50 \\
\hline Max. & 3 & 141 & 49 & 163 & 356 \\
\hline Min. & 2 & $62(52 \mathrm{~A}, 10 \mathrm{~J})$ & $20(12 \mathrm{~A}, 8 \mathrm{~J})$ & $5 \mathrm{I}(2 \mathrm{SA}, 49 \mathrm{~J})$ & 135 \\
\hline
\end{tabular}


competition among vultures, with Himalayan Vulture dominant owing to its larger size. At three sites (15, 16 and 19), vultures were observed soaring but did not come down to feed, possibly owing to high food availability near those sites at the time of surveys. For example, at site 19 the survey team was informed of two horse carcasses about $24 \mathrm{~km}$ from the restaurant and subsequently heard that vultures arrived at the restaurant site five days after the team had departed.

Although it was not possible to wholly exclude movement of individuals between sites during the survey, this is unlikely. Therefore, using this vulture restaurant method it is reasonable to conclude that the population of vultures in Myanmar is at least 136 individuals, made up of at least: 62 White-rumped Vultures, 21 Slender-billed Vultures, 51 Himalayan Vultures and two Red-headed Vultures. Egyptian Vulture and Black Vulture were not recorded during surveys but this is not unexpected, since these species are solitary and have rarely been recorded in Myanmar.

The largest numbers of vultures were recorded in Shan State, at restaurants 7 and 9 (65 and 68 birds respectively). At the latter, this high figure was due to an exceptional number of Whiterumped Vultures (6o, compared to a mean of 16 at visited restaurants) and at the former it was due to an exceptional number of Himalayan Vultures (49, compared to a mean of 18 at visited restaurants). Large numbers of vultures were also recorded in Chin State (50 at restaurant 18; largely Himalayan Vultures) and in Kachin State (57 at restaurant 1; with over twice the number of Slender-billed Vultures of any other site). Red-headed Vulture was recorded only in Shan State, at two vulture restaurants (numbers 7 and 10).

\section{Potential threats}

Incidental conversations with local people during surveys suggest that, although diclofenac is used as an analgesic and anti-inflammatory drug in human medicine, it is not used as a veterinary drug in Myanmar. However, we speculate that the ban on the manufacture, import, and veterinary use of diclofenac in India may cause China (a major diclofenac manufacturer) to try to offload surplus drugs to Myanmar at attractive prices. Other potential threats noted during surveys were as follows:

Nest destruction: local people near Mine None village, southern Shan State reported destroying a large tree containing 89 vulture nests a few years prior to the survey, because they considered vultures disgusting and disliked them nesting close to the village.

Hunting: two Himalayan Vultures were found killed and their wings used as scarecrows in Sukhar and Chun Kyun villages, Chin State. Local people reported that they had eaten the meat to discover whether vulture flesh was palatable.

Poisoning: orchard owners in Tang Yang Township, northern Shan State, reported using ureabased fertilizer to kill cattle that enter their orchards, and people of Teinthaw village, Bhamo Township, Kachin State, reported using a poison known as Le Phyat Sae (meaning cut-throat chemical) to kill scavenging species, including birds.

Disease: livestock diseases are unlikely to be a threat as they are rarely passed to birds. There are annual outbreaks of foot-and-mouth disease (FMD) and haemorrhagic septicaemia during the dry and early rainy season throughout the survey areas. FMD casualties are usually eaten by local people, so do not provide food for vultures if they are found quickly.

\section{Discussion}

Analysis of historical data suggests that there has been a significant decline in numbers of Whiterumped, Slender-billed and Red-headed Vultures in Myanmar during the last century. Unlike the dramatic declines on the Indian Subcontinent, the decline in Myanmar has been gradual. The two resident Gyps species appear to have declined equally, with White-rumped Vulture remaining more abundant than Slender-billed Vulture. As well as declining in numbers, vultures in Myanmar have also undergone a significant range contraction in the last century. They appear to 
have been completely lost from their strongholds in central and southern lowland areas such as Minbu District, Yangon, Sittang Basin and Arakhan State. Recent anecdotal records largely concur with survey results, although they indicate that White-rumped Vulture persists in Chin State. Further surveys, preferably in the rainy season (summer) are required in Chin State to determine if it persists there and, if so, in what numbers.

Potential causes for these declines and range contractions were evaluated during a vulture conservation action plan workshop in August 2007 (BirdLife International in Indochina and BANCA 2007). The primary cause of historic declines seems likely to be food limitation owing to conversion of lowland plains and deciduous forests containing abundant wild ungulates to arable land, and heavy hunting of remaining wild ungulates. Hunting pressure remains high and species such as Gaur Bos gaurus and Banteng Bos javanicus, although quite common fifty years ago, are now largely absent. Even Sambar Cervus unicolor, muntjacs Muntiacus spp. and Wild Boar Sus scrofa are decreasing (BirdLife International 2005). This may explain why vultures are now seen less in areas of natural habitat which should support wild ungulates, and more in farmland where livestock can be scavenged. Traditional stocking practices allow livestock to roam freely in forest and secondary vegetation during the dry season. This is likely to increase the amount of carrion available to vultures if cattle mortalities go undetected by people. It is conceivable that insecurity may have led to a reduction in the amount of time people leave their cattle roaming free in some parts of Myanmar. Vultures are now confined to cattle farming areas in the north, in Kachin and Shan states, where they were historically less abundant. It is likely that they now occupy only sub-optimal habitat on the edge of their range and are still declining owing to food limitation from continuing habitat conversion, hunting of wild ungulates, and changing farming practices.

Now that vulture populations have reached very low levels, destruction of nesting colonies, hunting and accidental poisoning appear to be the most immediate threats to the remaining birds. In Myanmar vultures are regarded as "disgusting birds" associated with death and decay. In some parts of Myanmar vultures are caught and killed for no obvious reason but 'fun'. However, although poisons are commonly used throughout Myanmar for fishing and hunting, there is relatively little evidence for deliberate poisoning of vultures.

The surveys revealed that Myanmar still supports significant populations of both Whiterumped and Slender-billed Vultures, and at least a small population of Red-headed Vultures. It is likely that populations of these three species are larger than the minimum population estimates of 62,20 and two respectively derived from the survey (e.g. four years earlier, 78 White-rumped Vultures were seen together in southern Shan State; Htin Hla unpublished data). It was not possible to visit all possible locations during the survey, owing to active insurgency and accessibility issues and, during surveys, the team received information on vulture sightings from areas not surveyed, which may relate to additional individuals.

Surveys were biased towards Gyps vulture habitats at the usual upper elevational range for Red-headed Vulture (c.1,500 m) rather than the lowland dry dipterocarp and semi-evergreen forests favoured by Red-headed Vulture. This bias, and the belief that this species prefers smaller carcasses and is less social than the Gyps vultures (H. Rainey in litt. 2010), strongly suggests that these survey data do not reflect the true status of Red-headed Vulture in Myanmar. Nonetheless, although historical data suggest that it might always have been the scarcest resident vulture in Myanmar, it was formerly described as "common" in northern Myanmar (Stanford and Ticehurst 1938-1939) and the paucity of recent records suggest that it may have declined more severely than the Gyps species and may now be restricted to Shan State. Status surveys are needed in central Myanmar in forest habitats favoured by this species.

The population estimates for the two threatened Gyps species are not much lower than their minimum population estimates in Cambodia in 2004 (Wildlife Conservation Society et al. 2005). Since that time, more accurate population estimates indicate that Cambodian populations are at least twice the 2004 estimates (Pech and Rainey 2009). More surveys are needed to increase the accuracy of population estimates in Myanmar, following the simultaneous restaurant protocol developed in Cambodia (Wildlife Conservation Society et al. 2005). In the present study, double 
counting was possible because Gyps vultures are known to have very large home ranges, e.g., up to $68,930 \mathrm{~km}^{2}$ for White-rumped Vulture (Gilbert et al. 2007), and some birds may have visited more than one restaurant.

The surveys confirmed the presence of a small number of Himalayan Vultures in Myanmar, although this constitutes a tiny proportion of the world population (BirdLife International 2010b). This species was not recorded in Myanmar before 2004, but was widespread and sometimes found in relatively high numbers during these surveys. Almost all records have been of juveniles and subadults, indicating post-natal dispersal from Himalayan breeding areas. It is possible that the species was overlooked historically owing to low observer coverage (with most surveys focused in forested areas in spring, rather than in open areas in winter), perhaps due to the similarity of juvenile Himalayan Vulture to White-rumped Vulture (though the former is much larger). It is also conceivable that the number of Himalayan Vultures visiting Myanmar has remained stable, whilst populations of breeding vultures have declined: with increased attention given to identifying every individual vulture and an increase in the proportion of vultures which are Himalayan, the true status of this species in the country may have been revealed. However, it is also possible that there has been a genuine change in status, possibly caused by Himalayan Vulture replacing formerly common resident species as they declined. Yong and Kasorndorkbua (2008) review Himalayan Vulture records across Indochina in recent years, south to Peninsular Malaysia and Singapore, and suggest that this reflects genuine status changes - speculating, in particular, linkages to wild ungulate declines owing to increased hunting in the traditional range of the species. Himalayan Vulture is not a focus of conservation action in Myanmar, because it is not currently threatened and the country does not support a globally significant population of the species. However, rapid declines in Himalayan Vulture populations in Nepal (though not in Tibet; Xin Lu et al. 2009), possibly owing to exposure of dispersing young birds to diclofenac outside of breeding areas (Acharya et al. 2009), suggest close monitoring of populations in Myanmar is advisable.

There are currently thought to be about 11,00o White-rumped Vultures and 1,00o Slenderbilled Vultures on the Indian Subcontinent (Prakash et al. 2007). Although these figures are considerably higher than the minimum population estimates for Myanmar, populations on the Indian Subcontinent continue to decline rapidly and their extinction is still a real possibility (Pain et al. 2008). Moreover, although the manufacture, import and veterinary use of diclofenac has been banned in India, widespread enforcement of these bans does not yet exist (R. Cuthbert in litt. 2010). Although the population of Gyps vultures in Myanmar may be relatively small, its global significance lies, as in Cambodia, in the fact that diclofenac is not used. With careful management of other threats, Myanmar could constitute a second diclofenac-free refuge for White-rumped, Slender-billed and Red-headed Vultures.

The vulture action plan for Myanmar identifies two main actions needed to ensure that the vulture populations are viable in the long term: research and conservation. The two main research priorities are to conduct simultaneous vulture restaurants annually across Myanmar to improve accuracy of population estimates and monitor trends, and to determine vulture ranging behaviour, either through satellite tagging or marking birds with wing tags to facilitate identification at vulture restaurants.

The most important conservation action is ensuring that diclofenac remains unused in Myanmar. This will require monitoring of veterinary practice and working with the government to ensure that veterinary use of the drug is banned in the country. In the northern cattle farming areas to which vultures are now restricted, provision of safe supplementary food at vulture restaurants would both ease any problems of food contamination or availability, and aid in monitoring. As populations of vultures in Myanmar are now small, there is a significant role for awareness-raising in reducing direct mortality. Raising general awareness on the value of vultures for the ecosystem and human health should be supplemented by awareness-raising about the harm that ordinary poisons can do to people, livestock and vultures if used inappropriately (poisoning is now the greatest threat to vultures in Cambodia), and development of a nest protection programme which includes location, reporting and protection of nests, especially of Red-headed Vulture. 
In conclusion, there have been significant declines in both populations and range of resident vulture species in Myanmar since historical times. However, these declines are for different reasons than recent dramatic declines in the Indian Subcontinent. Vulture populations in Myanmar therefore present a great opportunity to conserve diclofenac-free populations of three Critically Endangered vulture species, following a model established in Cambodia. To retain these as viable populations, it is of global importance that the research and conservation interventions proposed in the Myanmar vulture action plan are implemented in the next few years.

\section{Acknowledgements}

The authors thank the Royal Society for Protection of Birds and SwissAid for funding the vulture surveys. Our particular thanks go to the Nature and Wildlife Conservation Division, Forest Department, Ministry of Forestry, for collaboration in this survey. We also thank U Kyaw Kyaw Han (Chatthin Wildlife Sanctuary) and U Htun Win (Pe Taung Wildlife Sanctuary) for their assistance in eastern Kachin State, U Moe Myint Aung and U Myo Win (Htamanthi Wildlife Sanctuary) for their help in the U Yu River survey, U Sein Htun (Inn Daw Gyi Wildlife Sanctuary), U Myint Maung (Hukaung Tiger Reserve), U Shein Gay Ngyne (Namataung National Park), many staff from the Forest Department for their assistance and logical support throughout the fieldwork, and Hugo Rainey for very constructive comments on the manuscript. Lastly, the survey team were extremely grateful for their excellent driver Ko Win Maung in the rugged terrain of Chin State.

\section{References}

Acharya, R., Cuthbert, R., Baral, H. E. and Shah, K. B. (2009) Rapid population declines of Himalayan Griffon Gyps himalayensis in Upper Mustang, Nepal. Bird Conserv. Int. 19: 99-107.

BirdLife International (2001) Threatened birds of Asia: the BirdLife International Red Data Book. Cambridge, UK: BirdLife International.

BirdLife International (2005) Myanmar investment opportunities in biodiversity conservation. Yangon: Critical Ecosystem Partnership Fund, BirdLife International in Indochina and UNDP.

BirdLife International (2010a) Species factsheets: Gyps bengalensis, Gyps indicus, Gyps tenuirostris, Sarcogyps calous. Downloaded from http://www.birdlife.org on 23/07/2010.

BirdLife International (2010b) Species factsheet: Gyps himalayensis. Downloaded from http://www.birdlife.org on 23/07/2010.

BirdLife International in Indochina and Biodiversity And Nature Conservation Association (BANCA) (2007) Vulture action plan: Myanmar. Unpublished report.
Casey, M. (2007) Rare vulture shot dead in Myanmar after being freed in Thailand. Associated Press news article, 22 November 2007.

Christison, S. P., Buxton, A., Emmet, A. M. and Ripley, D. (1946) Field notes on the coastal Arakhan and the foothills of the Yomas. J. Bombay Nat. Hist. Soc. 46: $13-32$.

Cuthbert, R., Green, R. E., Ranade, S., Saravanan, S., Pain, D. J., Prakash, V. and Cunningham, A. A. (2006) Rapid population declines of Egyptian vulture (Neophron percnopterus) and red-headed vulture (Sarcogyps calvus) in India. Anim. Conserv. 9: 349-354.

Das, D., Cuthbert, R. J., Jakati, R. D. and Prakash, V. (in press) Diclofenac is toxic to the Himalayan Vulture Gyps himalayensis. Bird Conserv. Int. doi: 10.1017/ So959270910000171.

Ferguson-Lees, J. and Christie, D. A. (2001) Raptors of the world. London: Helm.

Gilbert, M., Virani, M. Z., Watson, R. T., Oaks, J. L., Benson, P. C., Khan, A. A., Ahmed, S., Chaudhry, J., Arshad, M., 
Mahmood, S. and Shah, Q. A. (2002) Breeding and mortality of Oriental Whitebacked Vulture Gyps bengalensis in Punjab Province, Pakistan. Bird Conserv. Int. 12: 311-326.

Gilbert, M., Watson, R. T., Ahmed, S., Asim, M. and Johnson, J. A. (2007) Vulture restaurants and their role in reducing diclofenac exposure in Asian vultures. Bird Conserv. Int. 17: 63-77.

Green, R. E., Newton, I., Shultz, S., Cunningham, A. A., Gilbert, M., Pain, D. J. and Prakash, V. (2004) Diclofenac poisoning as a cause of vulture population declines across the Indian subcontinent. J. Appl. Ecol. 41: 793-800.

Hopwood, C. (1912) A list of birds from Arakhan. J. Bombay Nat. Hist. Soc. 21: 1196-1221.

Macdonald, K. C. (1906) A list of birds found in the Myingyan district of Burma. J. Bombay Nat. Hist. Soc. 17: 184-194, 492-502.

Oaks, J. L., Gilbert, M., Virani, M. Z., Watson, R. T., Meteyer, C. U., Rideout, B. A., Shivaprasad, H. L., Ahmed, S., Chaudhry, M. J. I., Arshad, M., Mahmood, S., Ali, A. and Khan, A. A. (2004) Diclofenac residues as the cause of vulture population decline in Pakistan. Nature 427: 630-633.

Pain, D. J., Cunningham, A. A., Donald, P. F., Duckworth, J. W., Houston, D. C., Katzner, T., Parry-Jones, J., Poole, C., Prakash, V., Round, P. and Timmins, R. (2003) Causes and effects of temporospatial declines of Gyps vultures in Asia. Conserv. Biol. 17: 661-671.

Pain, D. J., Bowden, C. G. R., Cunningham, A. A., Cuthbert, R., Das, D., Gilbert, M., Jakati, R. D., Jhala, Y., Khan, A. A., Naidoo, V., Oaks, J. L., Parry-Jones, J., Prakash, V., Rahmani, A., Ranade, S. P., Baral, H. S., Senacha, K. R., Saravanan, S., Shah, N., Swan, G., Swarup, D., Taggart, M. A., Watson, R. T., Virani, M. Z., Wolter, K. and Green, R. E. (2008) The race to prevent the extinction of South Asian vultures. Bird Conserv. Int. 18: 30-48.

Pech, Bunnat and Rainey, H. J. (2009) Cambodia Vulture Conservation Project: Annual activities report. Unpublished Wildlife Conservation Society report.
Prakash, V. (1999) Status of vultures in Keoladeo National Park, Bharatpur, Rajasthan, with special reference to population crash in Gyps species. J. Bombay Nat. Hist. Soc. 96: 365-378.

Prakash, V., Pain, D. J., Cunningham, A. A., Donald, P. F., Prakash, N., Verma, A., Gargi, R., Sivakumar, S. and Rahmani, A. R. (2003) Catastrophic collapse of Indian white-backed Gyps bengalensis and longbilled Gyps indicus vulture populations. Biol. Conserv. 109: 381-390.

Prakash, V., Green, R. E. Pain, D. J., Ranade, S. P., Saravanan, S. and Prakash, N. (2007) Recent changes in populations of resident Gyps vultures in India. J. Bombay Nat. Hist. Soc. 104: 129-135.

Robson, C. (2005) Birds of South-East Asia. London: New Holland Publishers (UK) Ltd.

Robson, C. (2006) From the Field. Birding Asia 5: 88-93.

Robson, C. R., Buck, H., Farrow, D. S., Fisher, T. and King, B. F. (1998) A birdwatching visit to the Chin Hills, West Burma (Myanmar), with notes from nearby areas. Forktail 13: 109-120.

Roseveare, W. L. (1950) Notes on Birds of the irrigated area of Minbu District, Burma. J. Bombay Nat. Hist. Soc. 49: 244-287.

Smythies, B. E. (1986) The birds of Burma. Third (revised) edition. Liss, UK: Nimrod Press, and Pickering, Ontario: Silvio Mattachione and Co.

Stanford, J. K. and Ticehurst, C. B. (1935) Notes on the birds of the Sittang-Irrawaddy Plain, Lower Burma. J. Bombay Nat. Hist. Soc. 37: 859-899.

Stanford, J. K. and Ticehurst, C. B. (19381939) On the birds of northern Burma. Ibis (14) 2: 65-102, 197-229, 391-428, 599-638; (14) 3:1-45, 211-258.

Thiollay, J.-M. (2000) Vultures in India. Vulture News 42: 36-38.

Timmins, R. J. and Ou, Ratanak (2001) The importance of Phnom Prich Wildlife Sanctuary and adjacent areas for the conservation of tigers and other key species. Hanoi, Vietnam: World Wide Fund for Nature Indochina Programme.

Tordoff, A. W., Appleton, T., Eames, J. C., Eberhardt, K., Htin Hla, Khin, Ma Ma 
Thwin, Zaw, Sao Myo, Saw, Moses and Aung, Sein Myo (2007) Avifaunal surveys in the lowlands of Kachin State, Myanmar, 2003-2005. Nat. Hist. Bull. Siam Soc. 55: 235-306.

Virani, M., Gilbert, M., Watson, R., Oaks, L., Benson, P., Kham, A. A., Baral, H. S. and Giri, J. B. (2001) Asian vulture crisis project: field results from Pakistan and Nepal for the 2000-2001 field season. Pp. 7-9 in T. Katzner and J. Parry-Jones, eds. Reports from the workshop on Indian Gyps vultures, $4^{\text {th }}$ Eurasian congress on raptors, Sevilla, Spain, September 2001. Seville, Spain: Estación Biológica Donaña Raptor Research Foundation.
Wildlife Conservation Society, BirdLife International, World Wide Fund for Nature, Ministry of Environment and Ministry of Agriculture, Forestry and Fisheries (2005) Cambodia vulture conservation action plan. Unpublished report.

$\mathrm{Lu}$, Xin, Ke, Dianhua, Zeng, Xianhai, Gong, Guohong and Ci, Ren (2009) Status, ecology, and conservation of the Himalayan Griffon Gyps himalayensis (Aves, Accipitridae) in the Tibetan Plateau. Ambio 38: 166-173.

Yong, D. L. and Kasorndorkbua, C. (2008) The status of Himalayan Griffon Gyps himalayensis in South-East Asia. Forktail 24: 57-62.

\section{HTIN HLA, THURA WIN HTUN, SAO MYO ZAW}

Biodiversity and Nature Conservation Association, Yangon, Myanmar.

\section{NAY MYO SHWE}

Nature and Wildife Conservation Division, Forest Department, Ministry of Forestry, Myanmar.

SIMON MAHOOD ${ }^{\dagger}$, JONATHAN C. EAMES*, JOHN D. PILGRIM ${ }^{\ddagger}$

BirdLife International in Indochina, P.O. Box 89, 6 Dinh Le, Hanoi, Vietnam.

${ }^{\dagger}$ Current address: Fauna \& Flora International, 340 Nghi Tam, Hanoi, Vietnam.

${ }^{\ddagger}$ Current address: House 39/130 Nichakorn Place, Soi Nichada Thani, Samakee Road, Pakkret, Nontaburi 11120, Thailand.

${ }^{*}$ Author for correspondence; email: eames@birdlife.org.vn

Received 14 April 2010; revision accepted 9 August 2010; Published online 5 January 2011 


\begin{tabular}{|c|c|c|c|c|c|c|c|}
\hline \multicolumn{8}{|c|}{ Appendix 1 . Details of vulture restaurants } \\
\hline Site & Dates & Easting & Northing & $\begin{array}{l}\text { Elevation } \\
\text { (m. a.s.l.) }\end{array}$ & State & Location & Habitat \\
\hline VRI & 5 to 6.12 .06 & $25 \mathrm{H} 2 \mathrm{O}^{\prime} 26^{\prime \prime}$ & $96 \mathrm{H} 27^{\prime} 11^{\prime \prime}$ & $<200$ & Kachin State & Naung Khwin Inn,Indawgyi & Dry wetland \\
\hline $\mathrm{VR}_{2}$ & 8 to 10.12 .06 & $25 \mathrm{H} 19^{\prime} 12^{\prime \prime}$ & 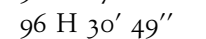 & $<200$ & Kachin State & Indaw Chaung & Grassland \\
\hline $\mathrm{VR}_{3}$ & 18 to20.12.06 & $24 \mathrm{H} 47^{\prime} 26.4^{\prime \prime}$ & $97 \mathrm{H} \mathrm{o2}^{\prime} 18.1^{\prime \prime}$ & $<200$ & Kachin State & Sinbo & Sandbar \\
\hline $\mathrm{VR}_{4}$ & 24 to 26.12 .06 & $24 \mathrm{H} 23^{\prime} 47 \cdot 6^{\prime \prime}$ & $97 \mathrm{H} 14^{\prime} 12.0^{\prime \prime}$ & $<200$ & Kachin State & Tain Thaw Village, Bahmo township & Fallow land \\
\hline $\mathrm{VR}_{5}$ & 30 to 1.1 .07 & $23 \mathrm{H} 46^{\prime} 30.8^{\prime \prime}$ & $97 \mathrm{H} 34^{\prime} 36.4^{\prime \prime}$ & $>_{1,200}$ & Northern Shan State & Hin Lonn Village, Namkham township & Shifting cultivation \\
\hline VR6 & 4 to 6.1 .07 & $23 \mathrm{H} 28^{\prime} 25.0^{\prime \prime}$ & $97 \mathrm{H} 25^{\prime} 56.0^{\prime \prime}$ & $>_{1,200}$ & Northern Shan State & Awel LawVillage, Manton township & Dry deciduous forest \\
\hline $\mathrm{VR}_{7}$ & 1o to 12.1 .07 & $23 \mathrm{H} \mathrm{O2}^{\prime} 28.1^{\prime \prime}$ & $98 \mathrm{H} \mathrm{o5}^{\prime} 00.4^{\prime \prime}$ & $>_{1,200}$ & Northern Shan State & Mine Yaw Village, Lashio township & Fallow land \\
\hline VR8 & 18 to 20.1 .07 & $22 \mathrm{H} 30^{\prime} 27 \cdot 5^{\prime \prime}$ & 98 H $19^{\prime} 13.6^{\prime \prime}$ & $>_{1,200}$ & Northern Shan State & Kho Yaung Village, Tanyang township & Rice paddy \\
\hline $\mathrm{VR}_{9}$ & 24 to 26.1 .07 & $21 \mathrm{H} 42^{\prime} 55 \cdot 3^{\prime \prime}$ & $97 \mathrm{H} 59^{\prime} 45.8^{\prime \prime}$ & $>_{1,200}$ & Southern Shan State & Mine None Village, Maing Naung township & Rice paddy \\
\hline VRio & 29 to 31.1 .07 & $20 \mathrm{H} 47^{\prime} 50.7^{\prime \prime}$ & $97 \mathrm{H} 39^{\prime} 15.0^{\prime \prime}$ & $>_{1,200}$ & Southern Shan State & Naung Pho Mae Village, Nam Sam township & Cattle pasture \\
\hline VRi1 & 16 to 18.2 .07 & $25 \mathrm{H} 20^{\prime} 31.5^{\prime \prime}$ & 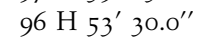 & $<200$ & Kachin State & Naung Pa Sauk Inn, Moe Kaung & Cattle pasture \\
\hline$V_{12}$ & 21 to 23.2 .07 & $25 \mathrm{H} 47^{\prime} 15.5^{\prime \prime}$ & $96 \mathrm{H} 38^{\prime \prime} 07.4^{\prime \prime}$ & $<200$ & Kachin State & Moe Kaung Chaung,Warazup village & Sandbar \\
\hline $\mathrm{VR}_{13}$ & 26 to 28.2 .07 & 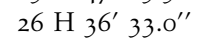 & 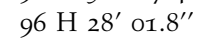 & $<200$ & Kachin State & Taroung village, Tanai township & Rice paddy \\
\hline $\mathrm{VR}_{14}$ & 7 to 9.3 .07 & $25 \mathrm{H} 48^{\prime}$ O2.9" & $95 \mathrm{H}_{31^{\prime}}^{\prime} 48.4^{\prime \prime}$ & $<200$ & Sagaing Division & Lin Far village Khamti township & Sandbar \\
\hline VR15 & 13 to 15.3 .07 & 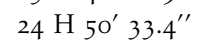 & $95 \mathrm{H}^{\prime}{ }^{\prime} 52.2^{\prime \prime}$ & $<200$ & Sagaing Division & Kin village, Homalin township & Sandbar \\
\hline VRi6 & 18 to 20.3 .07 & 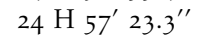 & $95 \mathrm{H} 29^{\prime} 18.2^{\prime \prime}$ & $<200$ & Sagaing Division & NamTha, Ton MaTat village & Rice paddy \\
\hline $\mathrm{VR}_{17}$ & 15 to 17.4 .07 & $21 \mathrm{H} 13^{\prime} 34.0^{\prime \prime}$ & 93 H $55^{\prime}$ oo. $2^{\prime \prime}$ & $>_{1,500}$ & Chin State & Mt. Victoria & Montane savanna \\
\hline $\mathrm{VR}_{1} 8$ & 20 to 22.4 .07 & $22 \mathrm{H} \mathrm{IO}^{\prime} 25 . \mathrm{I}^{\prime \prime}$ & $93 \mathrm{H}_{3} 6^{\prime} 06.6^{\prime \prime}$ & $>_{1,500}$ & Chin State & Bwe Par range, Aikhar village & Sandbar \\
\hline VR19 & 26 to 28.4 .07 & $22 \mathrm{H} 44^{\prime} 58.9^{\prime \prime}$ & $93 \mathrm{H}_{34}^{\prime} 32.0^{\prime \prime}$ & $>_{1,500}$ & Chin State & Chun Kyun village, Hakha township & Shifting cultivation \\
\hline$V_{2} O$ & I to 3.5 .07 & $23 \mathrm{H}_{16}^{\prime} 54 \cdot \mathrm{I}^{\prime \prime}$ & $93 \mathrm{H} 46^{\prime}$ оo. $7^{\prime \prime}$ & $>_{1,500}$ & Chin state & Akluai village, Tiddim township & Montane savanna \\
\hline
\end{tabular}

